\section{Genetic Diversity in Black Raspberry Detected by RAPD Markers}

\author{
C.A. Weber ${ }^{1}$ \\ Department of Horticultural Sciences, New York State Agricultural Experiment \\ Station, Cornell University, Geneva, NY 14456
}

Additional index words. black cap, PHYLIP, relatedness, raspberry breeding, cultivar identification, similarity matrix, distance matrix, Rubus occidentalis

\begin{abstract}
Lack of variation among black raspberry cultivars is thought to be a limiting factor in fruit production and in breeding improved cultivars. An assessment of the available diversity in black raspberry is needed to effectively develop improved cultivars. Such an assessment was done to estimate the genetic similarities for RAPD markers in 16 black raspberry genotypes and to determine the genetic diversity among these genotypes based on these markers. In addition, the ability to distinguish between the black raspberry genotypes, two red raspberry cultivars (Rubus idaeus $\mathbf{L}$.), and a blackberry cultivar (Rubus hybrid) was determined. A similarity matrix from 379 RAPD markers was calculated, and a phylogenetic tree was constructed using the PHYLIP suite of phylogeny software, which revealed the relationship among the genotypes. An average of $81 \%$ similarity was calculated among 16 black raspberry genotypes with a maximum similarity of $98 \%$ and a minimum of $70 \%$. The average similarity between black raspberry and red raspberry was $41 \%$ and was $26 \%$ between black raspberry and blackberry. Combined marker profiles from six RAPD primers could be used to distinguish between the 16 black raspberry genotypes. Red raspberry and blackberry could be distinguished from black raspberry by 27 and 29 of 30 RAPD primers tested, respectively. Genetic diversity was most prominent in genotypes from the extremes of the black raspberry indigenous range. Diversifying the germplasm pool for black raspberry cultivar improvement can be achieved through utilizing genotypes from the extremes of the black raspberry range and through interspecific hybridization.
\end{abstract}

Large-scale black raspberry production for much of the United States, especially for fresh consumption, is limited by the lack of superior cultivars available to growers (Ourecky, 1975). As demand for locally grown fruit has risen with regional marketing campaigns such as "Pride of NY" and "Ohio Proud," the supply has lagged in large part due to the lack of suitable cultivars. In addition, Oregon, the only major production region in the U.S., has experienced a decreased field life of the most widely planted cultivar, 'Munger', due to increased disease pressure.

Little variation in harvest season, fruit size, disease resistance, or other characteristics is observed among most cultivars. Varying theories on this lack of variation have been suggested including the lack of effort in breeding new cultivars (Daubeny, 1996) and the lack of genetic diversity within the species (Ourecky, 1975), but little research on the problem has been done. Whatever the cause, since comprehensive breeding for improved black raspberry cultivars is not a focus of current bramble breeding programs, many of the cultivars currently grown originated as wild selections or were developed from a very narrow germplasm pool.

While genotypes were distinguishable using mini-satellite DNA fingerprinting, in a single wild black raspberry population (Nybom and Schaal, 1990), variability among cultivars has

Received for publication 14 Mar. 2002. Accepted for publication 29 June 2002.

'E-mail address: caw34@nysaes.cornell.edu not been examined. In order to utilize available variability within black raspberry for cultivar development, an assessment of variation in current black raspberry cultivars is crucial to achieving improvement.

Use of molecular markers, especially random amplified polymorphic DNA (RAPD) markers, has become a standard practice for investigating genetic diversity in plants. The relationship among citrus (Gulsen and Roose, 2001), Malus sp. (Oraguzie et al., 2001), and eggplant (Solanum melongena L.) (Karihaloo et al. 1995) genotypes has been characterized using RAPD markers. Sanz-Cortés et al. (2001) identified olive (Olea europaea L.) cultivars and Welsh et al. (1991) determined maize (Zea mays L.) parentage using these markers. RAPD markers have also been utilized in many Rubus species for cultivar identification (Graham et al., 1994; Moore, 1995; Parent et al., 1993), interspecific relationship determination (Graham and McNicol, 1995), and spatial diversity identification in wild populations of $R$. idaeus L. (Graham et al., 1997). In this study, the genetic relationship among and between black raspberry, red raspberry (R. idaeus L.), and a blackberry hybrid (Rubus hybrid) genotypes was analyzed using RAPD markers.

\section{Materials and Methods}

Plant material. Sixteen black raspberry genotypes (14 cultivars and two wild selections), obtained from the U.S. Dept. of Agriculture/Agricultural Research Service (USDA/ARS) National Clonal Germplasm Repository in Corvallis, Ore., or from Cornell Univ.'s New York State Agricultural Experiment Station, Geneva, N.Y. (Table 1), were analyzed. The indigenous range of black raspberry is eastern North America extending from Quebec and Minnesota in the north to Georgia and Missouri in the south and west to the Rocky Mountains. Germplasm from nine states within this area was represented in the study. In addition, one blackberry hybrid and two red raspberry cultivars at Geneva were included as a reference and for comparisons between Rubus types (Table 1).

DNA extraction and RAPD marker generation. DNA was extracted from newly expanded leaves using the CTAB extraction method of Graham and McNicol(1995) without the muslin filtration. About $1 \mathrm{~g}$ of fresh tissue was frozen in liquid nitrogen and ground to a fine powder. The DNA was pelleted after precipitation by centrifuging at $12000 \mathrm{rpm}$ at $4{ }^{\circ} \mathrm{C}$ and resuspended in $1 \times$ Tris-EDTA (TE) buffer (Sambrook et al., 1989). DNA dilutions of $2 \mathrm{ng} \cdot \mu \mathrm{L}^{-1}$ were made from the concentrated stocks for amplification. RAPD primers, commercially available from the Univ. of British Columbia, Vancouver, Canada, were used for screening the sample array. The primers used were screened previously for activity in red

Table 1. Rubus genotypes evaluated for diversity using RAPD markers and their germplasm origin.

\begin{tabular}{|c|c|c|c|}
\hline Cultivar & Species & Germplasm origin & Citation \\
\hline Black Hawk & $R$. occidentalis & Kansas/Missouri & Lantz and Denisen, 1954 \\
\hline Black Knight & R. occidentalis & West Virginia & USDA, ARS, 2002a \\
\hline Bristol & $R$. occidentalis & Ohio/New York & Slate, 1938 \\
\hline Cumberland & R. occidentalis & Ohio & Hedrick, 1925 \\
\hline Dundee & $R$ occidentalis & New York/Ohio & Slate, 1938 \\
\hline Earlysweet & R. occidentalis & North Carolina/Ohio/New York/Oregon & Galletta et al., 1998 \\
\hline Hanover & $R$ occidentalis & Indiana & USDA, ARS, 2002b \\
\hline Haut & $R$ occidentalis & North Carolina/Ohio/New York & Hedrick, 1925 \\
\hline Huron & R. occidentalis & New York/Ohio & Slate, et al, 1965 \\
\hline Jewel & R. occidentalis & New York/Ohio & Ourecky and Slate, 1973 \\
\hline John Robertson & $R$ occidentalis & South Dakota & --- \\
\hline Munger & R. occidentalis & New York & Hedrick, 1925 \\
\hline New Logan & R. occidentalis & Illinois & Johnson, 1932 \\
\hline NY99-60 & R. occidentalis & New York & --- \\
\hline NY99-61 & $R$. occidentalis & New York & --- \\
\hline Plum Farmer & R. occidentalis & Ohio & Hedrick, 1925 \\
\hline Heritage & $R$. idaeus & New York & Ourecky, 1969 \\
\hline Prelude & R. idaeus & New York & Maloney et al., 1998 \\
\hline Illini Hardy & Rubus hybrid & Illinois/New York & Skirvin and Otterbacher, 1991 \\
\hline
\end{tabular}


raspberry. Additionally, primers were tested on a subset of six black raspberry cultivars for activity and to identify markers that could be scored.

PCR was done using the method of Cai et al. (1994) scaled for $50 \mu$ L reactions. The amplification took place in a PTC-100 Programmable Thermal Controller (MJ Research, Watertown, Mass.) with a heated lid under the following block temperature cycle: $93{ }^{\circ} \mathrm{C}$ for $2 \mathrm{~min}, 42$ cycles at $93{ }^{\circ} \mathrm{C}$ for $1 \mathrm{~min}, 35^{\circ} \mathrm{C}$ for $1 \mathrm{~min}, 72$ ${ }^{\circ} \mathrm{C}$ for $2 \mathrm{~min}$., followed by $72^{\circ} \mathrm{C}$ for $5 \mathrm{~min}$ and then ramped to $4{ }^{\circ} \mathrm{C}$ to hold the reaction. Amplification products from all 19 genotypes were resolved simultaneously on $2 \%$ agarose gels run in $1 \times$ TAE buffer at $60 \mathrm{mV}$ for $3 \mathrm{~h}$ in a wide mini-sub cell GT unit (Bio-Rad Laboratories, Hercules, Calif.) They were then stained with ethidium bromide, and visualized with ultraviolet illumination. Each amplification was repeated to verify marker scoring.

Data analysis. A similarity matrix for the genotypes was calculated using the method of Graham et al. (1997) where the similarity between two genotypes is determined as $2 d /$ $(b+c+2 d)$, where $d$ is the number of marker bands shared by the two genotypes and $b$ and $c$ are those in one genotype or the other, but not both. Bands absent in both genotypes of a pair are not used in the computation of that particular similarity value. A distance matrix was also calculated using the RESTDIST program from the PHYLIP suite of phylogeny software (Felsenstein, 2000). The genotypes were grouped and a phylogenetic tree produced using the unweighted pair-group method analysis (UPGMA) option in the NEIGHBOR program from the PHYLIP suite.

\section{Results}

Of the 379 markers scored from 30 RAPD primers, $228(60 \%)$ markers were present in black raspberry including 13 that were mono- morphic across all three species. A total of 151 $(40 \%)$ were present in only red raspberry or blackberry and not present in black raspberry. Most markers were useful for group differentiation with 366 (97\%) markers showing variation among the black raspberry, red raspberry, and blackberry groups. Of these, $225(59 \%)$ had variation between the groups but showed no variation within the black raspberry group, 74 (19\%) were monomorphic and 151 (40\%) were absent from black raspberry. This variability allowed the blackberry genotype to be distinguished from the raspberries by marker profiles of 29 of 30 primers used in this study. In addition, 27 of 30 primers screened were able to distinguish between all three groups in this study.

Of the 228 markers scored in the 16 black raspberry genotypes, 87 (38\%) were monomorphic and $141(62 \%)$ were polymorphic. Slightly more than half $(52 \%)$ of the 141 polymorphic markers showed variation in only one $(38 \%)$ or two $(14 \%)$ of the black raspberry genotypes. Of the markers scored in black raspberry, 160 (70\%) showed variation in two or fewer of the 16 black raspberry genotypes. However, combined marker profiles from six primers (Table 3 ) could be used to differentiate all 16 black raspberry genotypes. An analysis of similarity among the genotypes showed a very close relationship among the black raspberry genotypes with an average of $81 \%$ similarity. The range was from $98 \%$ similarity between 'Munger' and 'New Logan' to 70\% between 'Cumberland' and 'Black Hawk' (Table 3). 'Black Hawk', 'Cumberland', NY99-60, and 'John Robertson' had the least similarity on average to the 15 other genotypes. The cultivars 'Plum Farmer', 'Munger', 'New Logan', and 'Hanover' were the most similar to each other with an average of $97 \%$ similarity. The red raspberries and the blackberry hybrid displayed a low level of similarity to the black raspberry genotypes (Table 2) averaging $41 \%$ and $26 \%$ similarity, respectively. A phylogenetic tree constructed using the marker data displays the relationship among the genotypes (Fig. 1).

\section{Discussion}

Black raspberry diversity has been proposed to be inadequate (Ourecky, 1975) or too poorly sampled(Daubeny, 1996) for improved cultivar development. Based on the information in this study, both views are substantiated. As a whole, the genotypes show a level of similarity of $81 \%$ compared to $70 \%$ similarity measured among red raspberry cultivars (Graham et al., 1994). This compares to a study of 36 apple cultivars where most were between $52 \%$ and $73 \%$ similar with the range falling from $14.8 \%$ to $95.2 \%$ similarity (Oraguzie et al., 2001).

However, $58 \%$ of the calculated variability observed in black raspberry in this study is accounted for by five genotypes: 'Black Hawk', 'Cumberland', 'John Robertson', NY99-60, and NY99-61. 'Black Hawk' is a cultivar with 3 of 4 grandparents selected from the wild (Lantz and Denisen, 1954). 'Cumberland' is thought to be from open pollinated seed of a wild parent (Hedrick, 1925). 'John Robertson' is a wild selection (R.M. Peterson, personal communication), and both the NY selections were taken from the wild. This would seem to indicate a higher level of variability in the wild germplasm compared to cultivars. However, this conclusion is not corroborated by the origins of the remaining 11 genotypes. These cultivars originate both from wild selections and from breeding programs. Especially interesting is the lack of variation seen between cultivars such as 'Earlysweet', which has $R$. leucodermis as a parent (Galletta et al., 1998); 'Hanover', which was selected in the wild in Indiana (USDA, ARS, National Genetic Resources Program. 2002b); 'New Logan', which was selected from the wild in Illinois (Johnson, 1932); and 'Plum Farmer', which was a wild selection from Ohio (Hedrick, 1925). In fact, of

Table 2 . Similarity matrix among 16 black raspberry, 2 red raspberry, and 1 blackberry genotypes.

\begin{tabular}{|c|c|c|c|c|c|c|c|c|c|c|c|c|c|c|c|c|c|c|c|}
\hline & $\begin{array}{l}80 \\
\circ \\
2 \\
\text { خे } \\
\text { ż }\end{array}$ & 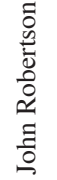 & 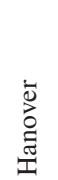 & 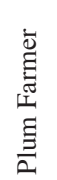 & 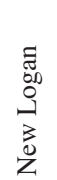 & $\begin{array}{l}\overline{\bar{D}} \\
\dot{\Xi} \\
\stackrel{\Xi}{\Sigma}\end{array}$ & $\begin{array}{l}\frac{\vec{t}}{.00} \\
\ddot{\Xi} \\
\frac{n}{0} \\
\frac{\pi}{0}\end{array}$ & $\begin{array}{l}\overline{0} \\
\stackrel{1}{2} \\
\text { ¿े } \\
\text { Z }\end{array}$ & 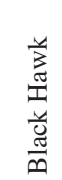 & 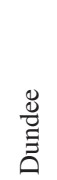 & 总 & $\begin{array}{l}\bar{D} \\
\stackrel{0}{\varrho}\end{array}$ & $\begin{array}{l}\overrightarrow{0} \\
\stackrel{0}{0} \\
\bar{n}\end{array}$ & $\begin{array}{l}\vec{\Xi} \\
\text { 壱 }\end{array}$ & 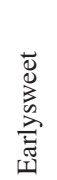 & 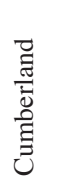 & $\begin{array}{l}\frac{8}{0} \\
\frac{0}{0} \\
\text { D. }\end{array}$ & 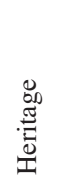 & 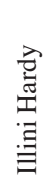 \\
\hline NY99-60 & 100 & & & & & & & & & & & & & & & & & & \\
\hline John Robertson & 89 & 100 & & & & & & & & & & & & & & & & & \\
\hline Hanover & 90 & 89 & 100 & & & & & & & & & & & & & & & & \\
\hline Plum Farmer & 91 & 90 & 95 & 100 & & & & & & & & & & & & & & & \\
\hline New Logan & 90 & 89 & 97 & 97 & 100 & & & & & & & & & & & & & & \\
\hline Munger & 90 & 89 & 97 & 97 & 98 & 100 & & & & & & & & & & & & & \\
\hline Black Knight & 91 & 91 & 91 & 92 & 92 & 92 & 100 & & & & & & & & & & & & \\
\hline NY99-61 & 82 & 84 & 88 & 87 & 88 & 88 & 88 & 100 & & & & & & & & & & & \\
\hline Black Hawk & 76 & 75 & 74 & 74 & 74 & 74 & 75 & 76 & 100 & & & & & & & & & & \\
\hline Dundee & 88 & 91 & 93 & 91 & 91 & 90 & 88 & 84 & 74 & 100 & & & & & & & & & \\
\hline Huron & 89 & 89 & 94 & 93 & 94 & 95 & 91 & 86 & 75 & 91 & 100 & & & & & & & & \\
\hline Jewel & 89 & 88 & 94 & 94 & 94 & 95 & 90 & 85 & 74 & 90 & 93 & 100 & & & & & & & \\
\hline Bristol & 90 & 91 & 96 & 97 & 96 & 97 & 90 & 87 & 75 & 91 & 94 & 95 & 100 & & & & & & \\
\hline Haut & 87 & 90 & 90 & 90 & 89 & 90 & 89 & 84 & 73 & 91 & 92 & 90 & 91 & 100 & & & & & \\
\hline Earlysweet & 84 & 87 & 90 & 89 & 90 & 90 & 86 & 84 & 75 & 91 & 89 & 87 & 90 & 90 & 100 & & & & \\
\hline Cumberland & 88 & 83 & 86 & 86 & 86 & 86 & 84 & 79 & 70 & 84 & 87 & 88 & 86 & 87 & 80 & 100 & & & \\
\hline Prelude & 43 & 42 & 42 & 42 & 42 & 43 & 42 & 40 & 40 & 44 & 42 & 44 & 42 & 39 & 45 & 37 & 100 & & \\
\hline Heritage & 38 & 38 & 40 & 41 & 40 & 40 & 41 & 39 & 35 & 43 & 42 & 42 & 40 & 41 & 43 & 40 & 67 & 100 & \\
\hline Illini Hardy & 27 & 26 & 25 & 26 & 26 & 26 & 29 & 25 & 28 & 25 & 25 & 26 & 24 & 23 & 25 & 22 & 33 & 28 & 100 \\
\hline
\end{tabular}


the 16 genotypes investigated, none were more than two generations from at least one wild ancestor. This suggests that many so-called "wild selections" are actually open pollinated escapes from cultivation. The $98 \%$ similarity between 'Munger', whose parent was a chance seedling found in New York, and 'New Logan', which originated as a chance seedling in Illinois, supports this conclusion.

The 11 least variable black raspberry genotypes showed a collective similarity of $92 \%$ and these cultivars account for the majority of the commercial production in North America. Monomorphic or near-monomorphic markers (two or fewer polymorphisms in the 16 genotypes) accounted for $70 \%$ of the markers scored. This compares to $62.8 \%$ found in tomato (Lycopersicon esculentum Mill.) (Williams and St. Clair, 1993) and 91.7\% in celery (Apium graveolens L.) (Yang and

Table 3. Random amplified polymorphic marker (RAPD) primers useful in differentiating black raspberry cultivars.

\begin{tabular}{lc}
\hline $\begin{array}{l}\text { Primer } \\
\text { identification }\end{array}$ & \multicolumn{1}{c}{ Sequence } \\
\hline BC35 & 5' CCGGGGTTAA 3' \\
BC211 & 5' GAAGCGCGAT 3' \\
BC354 & 5' CTAGAGGCCG 3' \\
BC424 & 5' ACGGAGGTTC 3' \\
BC506 & 5' CCTTTCCCGA 3' \\
BC563 & 5' CGCCGCTCCT 3' \\
\hline
\end{tabular}

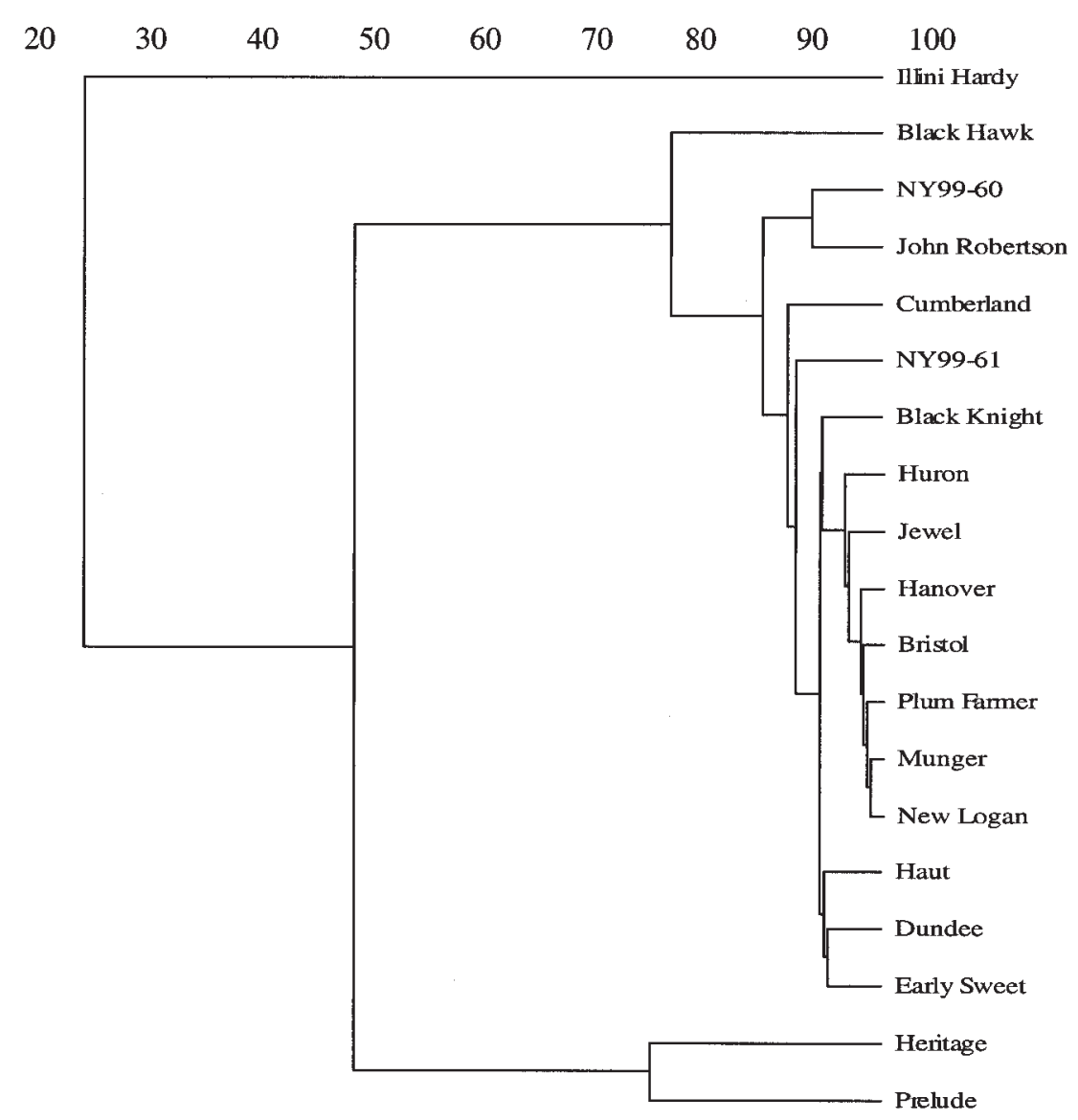

Fig. 1. Phylogenetic tree of 19 Rubus genotypes based on similarity of RAPD markers from 30 random primers. Scale is in \% similarity.

Quiros, 1993), which are levels considered quite highly monomorphic (Karihaloo et al., 1995).

The variation in this study between the species groupings agreed with previous reports. Graham and McNicol (1995) found an average of $40 \%$ similarity between a $R$. occidentalis accession and 11 red raspberry cultivars. This level of diversity suggests that differentiation of groups in Rubus should be relatively simple using RAPD markers regardless of sample size.

Daubeny (1996) suggested that genetic diversity in black raspberry might be found by sampling genotypes from the extremities of its range based on the higher than expected variability observed by Nybom and Schaal (1990) among a roadside population in Missouri. The data in this study suggest that this may be a valid approach to finding diverse germplasm for breeding new cultivars. The most variable genotypes in this study represent unusual research material, range extremes, or possible interspecific hybridization. NY99-60 and NY99-61 were both selected from wild populations for semi-smooth canes and yellow fruit, respectively, and do not fit the typical New York germplasm selections of superior fruit quality. 'John Robertson' was selected from the wild in North Dakota (R.M. Peterson, personal communication) and 'Black Hawk' originates in Kansas (Lantz and Denisen, 1954). These states approach the natural borders of the indigenous black raspberry range.

HortScience, Vol. 38(2), ApriL 2003
'Cumberland', on the other hand is from the center of the range, but is thought to have some blackberry in its background because its leaf shape is intermediate between blackberry and black raspberry (Hedrick, 1925). However, 'Earlysweet' and 'Black Knight' do not show the variability expected from their origin. 'Earlysweet' has a western black raspberry parent, $R$. leucodermis Dougl. (Galletta et al., 1998), and 'Black Knight' originates towards the southern edge of the range in West Virginia (USDA, ARS, National Genetic Resources Program, 2002a). An assessment of wild germplasm and cultivars from a wider section of black raspberry's indigenous range may be useful in identifying additional variation for utilization in a breeding program.

Most black raspberry cultivars show little diversity in horticultural traits such as fruiting season, fruit quality and size, and disease resistance (Ourecky, 1975) and are often difficult to distinguish using morphological characteristics. However, there are good indications that genotypes do exist with variation, at least at the molecular level. In addition, introgression of germplasm from $R$. idaeus and $R$. leucodermis shows great promise in introducing superior qualities of yield, disease resistance, and fruit quality. A multifaceted approach combining exploration of existing genetic diversity with introgression from compatible species will increase the diversity of black raspberry germplasm used in breeding and lead to the introduction of superior new cultivars.

\section{Literature Cited}

Cai, Q., C.L. Guy, and G.A. Moore. 1994. Extension of the linkage map in Citrus using random amplified polymorphic DNA (RAPD) markers and RFLP mapping of cold-acclimation-responsive loci. Theor. Appl. Genet. 89:606-614.

Daubeny, H.A. 1996. Brambles, p. 109-190. In: J. Janick and J.N. Moore (eds.). Fruit breeding. Vol. II. Vine and small fruits. Wiley, New York.

Felsenstein, J. 2000. PHYLIP Phylogeny Inference Package. Version 3.6. Dept. of Genetics, Univ. Washington, Seattle.

Galletta, G.J., J.L. Maas, and J.M. Enns. 1998. 'Earlysweet' black raspberry. Fruit Var. J. 52: 123-124.

Graham, J., R.J. McNicol, K. Greig and W.T.G. Van de Ven. 1994. Identification of red raspberry cultivars and an assessment of their relatedness using fingerprints produced by random primers. J. Hort. Sci. 69:123-130.

Graham, J. and R.J. McNicol. 1995. An examination of the ability of RAPD markers to determine the relationships within and between Rubus species. Theor. Appl. Genet. 90:1128-1132.

Graham, J., G.R. Squire, B. Marshall, and R.E. Harrison. 1997. Spatially dependent genetic diversity within and between colonies of wild raspberry Rubus idaeus detected using RAPD markers. Mol. Ecol. 6:1001-1008.

Gulsen, O. and M.L. Roose. 2001.Lemons: Diversity and relationships with selected Citrus genotypes as measured with nuclear genome markers. J. Amer. Soc. Hort. Sci. 126:309-317.

Hedrick, U.P. 1925. The small fruits of New York. J.B. Lyon Co., Albany, N.Y.

Johnson, S. 1932. The "New Logan" black raspberry. Michigan Quart. Bul.14(3):162.

Karihaloo, J.L., S. Brauner, and L.D. Gottlieb. 1995. 


\section{Breeding, Cultivars, Rootstocks, \& Germplasm Resources}

Random amplified polymorphic DNA variation in the eggplant, Solanum melongena L. (Solanaceae). Theor. Appl. Genet. 90:767-770.

Lamb, R.C., G.L. Slate, d. Ourecky, and J. Watson. 1965. Six new fruits named at Geneva station. Farm Res. 31(2):2-5.

Lantz, H.L. and E.L. Denisen. 1954. Black Hawk: A new raspberry for the Midwest. Iowa Farm Sci. 9(6):3-5.

Maloney, K.E., J.E. Reich, and J.C. Sanford. 1998. 'Prelude' red raspberry. New York's Food and Life Sciences Bul. 153. New York State Agr. Expt. Sta., Geneva, N.Y.

Moore, P.P. 1995. Distinguishing Pacific northwes red raspberry cultivars using RAPD markers. HortScience 30:833.

Nybom, H. and B.A. Schaal. 1990. DNA "fingerprints" reveal genotypic distributions in natural populations of blackberries and raspberries $(R u-$ bus, Rosaceae). Amer. J. Bot. 77:883-888.

Oraguzie, N.C., S.E. Gardiner, H.C.M. Basset, M. Stefanati, R.D. Ball, V.G.M. Bus, and A.G. White. 2001. Genetic diversity and relationships in Malus sp. germplasm collections as determined by randomly amplified polymorphic DNA. J. Amer. Soc. Hort. Sci. 126:318-328.

Ourecky, D.K. 1975. Brambles, p. 98-129. In J. Janick and J.N. Moore (eds.). Advances in fruit breeding. Purdue Univ. Press, West
Lafayette, Ind.

Ourecky, D.K.. 1969. Heritage, A new fall bearing red raspberry. Fruit Var. J. Hort. Dig. 23(4):78.

Ourecky, D.K. and G.L. Slate. 1973. Jewel black raspberry. New York's Food and Life Sci. Bul. 35. New York State Agr. Expt. Sta., Geneva, N.Y.

Parent, J.G., M.G. Fortin, and D. Pagé. 1993. Identification de cultivars de framboisier par l'analyse d' ADN polymorphe amplifié au hasard (RAPD). Can. J. Plant Sci. 73: 1115-1122.

Sambrook, J., E.F. Fritsch, and T. Maniatis. 1989 Molecular cloning: Alaboratory manual. $2^{\text {nd }} e d$. Laboratory Press, Cold Spring Harbor, N.Y.

Sanz-Cortés, F., J.L. Badenes, S. Paz, A. Íñiguez, and G. Llácer. 2001. Molecular characterization of olive cultivars using RAPD markers. J. Amer. Soc. Hort. Sci. 126:7-12.

Skirvin, R.M. and A.G. Otterbacher. 1991. What's new in Illinois blackberries for the 1990's? Proc. 1991 Ill. Small Fruit Strawberry School. Ill. Coop. Ext. Serv. Hort. Ser. 88:51-53.

Slate, G.L. 1938. New or noteworthy fruits, XII, Small fruits. New York State Agr. Res. Sta. Bul. 680.

U.S. Dept. of Agriculture, Agricultural Research Service, National Genetic Resources Program. 2002a. 'Black Knight'. Germplasm Resources Information Network-(GRIN). [Online Database] National Resources Laboratory, Beltsville, Md. Available: http://www.arsgrin.gov/cgi-bin/npgs/html/acc_search.pl?ac cid=PI +553754

U.S. Dept. of Agriculture, Agricultural Research Service, National Genetic Resources Program. 2002b. 'Hanover'. Germplasm Resources Information Network-(GRIN). [Online Database] National Resources Laboratory, Beltsville, Md. Available: http://www.arsgrin.gov/cgi-bin/npgs/html/acc_search.pl?ac cid $=\mathrm{PI}+553768$

Welsh, J., R.J. Honeycutt, M. McClelland, and B.W.S. Sobral. 1991. Parentage determination in maize hybrids using the arbitrarily primed polymerase chain reaction (AP-PCR). Theor. Appl. Genet. 82:473-476.

Williams, C.E. and D.A. St. Clair. 1993. Phenotypic relationships and levels of variability detected by restriction fragment length polymorphism and random amplified polymorphic DNA analysis of cultivated and wild accessions of Lycopersicon esculentum. Genome 36: 619-630.

Yang, X. and C. Quiros. 1993. Identification of celery cultivars with RAPD markers. Theor. Appl. Genet. 86:205-212. 